\title{
An analysis of amplified insulin gene products in diabetics of Indian origin
}

\author{
G A Hitman, P K Kambo, M Viswanathan, V Mohan
}

\begin{abstract}
We have previously described an increased incidence of the class 3 allele of the hypervariable region (HVR) $5^{\prime}$ to the insulin gene in south Indian noninsulin dependent diabetics; this association is absent in Punjabi Sikhs with this disorder. Using the polymerase chain reaction we have amplified parts of the insulin gene from 130 subjects to look for mutations which may be in linkage disequilibrium with the class 3 allele and hence explain its association with non-insulin dependent diabetes (NIDDM). In 23 south Indian subjects with NIDDM, using the restriction enzyme MboII, a B chain mutant (insulin Chicago) was excluded. Two patterns $(\alpha$ and $\beta$ ) were found, representing a PstI polymorphism in the $3^{\prime}$ untranslated region of the insulin gene. In subjects homozygous for the class 1 allele, the allelic frequency for $\alpha$ was $0.94(143 / 152)$ and for $\beta$ was 0.06 , in heterozygotes $(1,3) \alpha 0.63$ $(54 / 86)$ and $\beta 0.37$, and in homozygotes for the class 3 allele $\alpha 0.18(4 / 22)$ and $\beta 0.82(p<0.001)$, thus establishing linkage disequilibrium between these two loci. No differences in allelic frequency were found in the south Indians or Punjabi Sikhs between controls and the different types of non-insulin requiring diabetes (NIDDM, fibrocalculous pancreatic diabetes and maturity onset diabetes of the young) when both groups were matched for insulin genotypes. Thus, although this polymorphism in the $3^{\prime}$ untranslated region of the insulin gene is in linkage disequilibrium with the class 3 allele, it does not appear to be any better at predicting diabetes than the class 3 allele itself.
\end{abstract}

Despite strong evidence that non-insulin dependent diabetes (NIDDM) is a genetic disease, the progress

Department of Medicine, The London Hospital, Whitechapel, London, E1 1BB.

G A Hitman, P K Kambo

Diabetes Research Centre, Madras, India.

M Viswanathan, V Mohan

Correspondence to Dr Hitman.

Received for publication 7 June 1990.

Revised version accepted for publication 17 July 1990. in identifying the genes involved in its pathogenesis has been slow. This contrasts sharply with the recent advances in identifying genes involved in the susceptibility to insulin dependent diabetes. ${ }^{1}$ Several candidate genes for NIDDM have been investigated including those coding for insulin, ${ }^{2-7}$ the insulin receptor, ${ }^{6-10}$ the erythrocyte glucose transporter, ${ }^{11} 12$ and HLA, ${ }^{13-15}$ but no consistent association with NIDDM has been found. Furthermore, in pedigree studies, apart from the rare exception, linkage of proposed markers has not been found with NIDDM. ${ }^{1}$

Recent studies on diabetics from south India have indicated an association with non-insulin requiring diabetes (for example, NIDDM, ${ }^{7}$ maturity onset diabetes of the young (MODY) (unpublished), and fibrocalculous pancreatic diabetes (FCPD) ${ }^{7}$ ) of the class 3 allele of the hypervariable region in the $5^{\prime}$ flanking region of the insulin gene on chromosome 11. Furthermore, the association was particularly marked in those with a family history of NIDDM. Similar results have also been reported in a Japanese study. ${ }^{5}$ However, in a separate study we were unable to find the insulin gene association in north Indians (Punjabi Sikhs). ${ }^{6}$ Associations of this marker have been described in several ethnic groups but are absent in others. ${ }^{1}$ Many interpretations of these studies exist including the following.

(1) Spurious results leading to a false association.

(2) Ethnic heterogeneity in study groups.

(3) The primary association not being with NIDDM but an associated disorder (for example, atherosclerosis or hypertriglyceridaemia). ${ }^{16-18}$

(4) A high rate of recombination around the hypervariable region of the insulin gene. This would reduce the usefulness of the HVR as a polymorphic marker for a linked disease associated mutation in and around the insulin gene locus. Indeed, meiotic recombination of this locus occurs more frequently than one expects from its physical length. Thus Chakravarti $e t$ $a l^{19}$ have calculated by analysing four insulin gene locus polymorphisms (including the HVR) that the recombination frequency is 24 times greater than would be predicted.

(5) Linkage disequilibrium of the class 3 allele with either an aetiologically significant mutation within the insulin gene locus or a diabetogenic gene near to the insulin gene on chromosome 11. This might also 
explain the lack of an association of the hypervariable region of the insulin gene with NIDDM in some well defined ethnic groups, as one would postulate that the class 3 allele in these ethnic groups is no longer in linkage disequilibrium with the aetiological mutation. This situation would not be unique and would parallel findings in population studies of sickle cell disease. A polymorphism in the $3^{\prime}$ flanking region ( $\mathrm{HpaI}$ ) of the $\beta$ globin gene can be used to predict sickle cell disease in west but not east Africans, despite the aetiology of the disease being the same in the two ethnic groups, that is, a single amino acid substitution in the $\beta$ globin molecule. ${ }^{20}$

The aim of our study was to test the hypothesis that in non-insulin requiring diabetes in south Indian subjects there is a nucleotide substitution in the coding regions of the insulin gene and this in turn would be in linkage disequilibrium with the class 3 allele of the insulin gene locus which would account for its association with diabetes. Furthermore, in population groups who do not show an association of NIDDM with the class 3 allele (for example, Punjabi Sikhs) the same insulin gene locus mutant might also be found as in the south Indians, although not linked to the class 3 allele. The strategy adopted was to amplify areas of the coding region of the insulin gene using the polymerase chain reaction, ${ }^{21}$ digest these fragments with restriction enzymes, and separate the resulting fragments by polyacrylamide gel electrophoresis. Among the possible intragenic polymorphisms to be studied would be one of the $B$ chain determining insulin $\mathrm{Chicago}^{22}$ and another adjacent to the A chain in the $3^{\prime}$ untranslated region. ${ }^{23} 24$

\section{Methods}

SUBJECTS STUDIED

South Indian $(n=99)$ and Punjabi Sikh $(n=31)$ subjects were selected for analysis according to the presence or absence of the class 3 allele (determined from previous studies) ${ }^{67}$ In south Indian subjects the following groups were analysed: healthy controls $(n=26)$, NIDDM $(n=23)$, MODY $(n=24)$, and FCPD $(n=26)$. In Punjabi Sikhs only healthy controls $(n=17)$ and patients with NIDDM $(n=14)$ were studied. Clinical groups were defined as previously described. $^{7}$

\section{EXPERIMENTAL METHODS}

A total of $10 \mu$ l of $10 \times$ polymerase chain reaction (PCR) buffer $(500 \mathrm{mmol} / 1 \mathrm{KCl}, 100 \mathrm{mmol} / 1 \mathrm{Tris}-\mathrm{Cl}$, $\mathrm{pH} 8 \cdot 3,15 \mathrm{mmol} / 1 \mathrm{MgCl}_{2}, 0 \cdot 1 \% \mathrm{w} / \mathrm{v}$ gelatin), $16 \mu \mathrm{l}$ of dNTP $(1.25 \mathrm{mmol} / \mathrm{l}), 5 \mu \mathrm{l}$ of each primer (Oswell DNA Service, Edinburgh), and 200 ng of target DNA was mixed together with double distilled water to give a final volume of $100 \mu \mathrm{l}$. DNA in the PCR mix was then amplified in 40 cycles using Taq polymerase, $2 \cdot 5$ units/assay (Cetus Corporation) in a Techne heating block. The exact conditions for each cycle were as follows. (1) The B chain: one minute denaturing at $99^{\circ}$ followed by a combined step of three minutes annealing and extension at $68^{\circ} \mathrm{C}$ using two primers of sequence 5' ATCACTGTCCTTCTGCCATGG 3' and 5' CCTGCA GGTCCTCTGCCTCCC 3'. (2) The $A$ chain and $3^{\prime}$ untranslated region: one minute denaturing at $99^{\circ} \mathrm{C}, 18$ seconds annealing at $55^{\circ}$, and 2.5 minutes extension at $72^{\circ}$ using two primers of sequence 5' GCTGGTTCAAGGGCTTTATTC 3' and TGGGGCAGGTGGAGCTGGGCG 3'.

One tenth of the polymerase chain reaction product was then mixed with ethidium bromide and separated out on a $1 \cdot 5 \%$ agarose gel to check that a single sized product (218 bp for the A chain and $203 \mathrm{bp}$ for the B chain) had been obtained. A total of $50 \mu$ l of PCR product was then subjected to phenol/chloroform extraction, precipitated using ethanol and sodium acetate, and redissolved in $10 \mu \mathrm{l}$ of a Tris/EDTA buffer by previously described techniques. ${ }^{3}$ The A chain related PCR product in 51 subjects was digested with $50 \mathrm{U}$ of PvuII and $50 \mathrm{U}$ PstI. In the remaining subjects only PstI was used. The B chain related PCR product was digested with MboII and HaeIII and studied in 23 south Indian subjects, 12 of whom possessed the class 3 allele. The digested PCR products were separated according to size on $15 \%$ polyacrylamide gel (for 15 hours at 200 volts) and visualised after staining with ethidium bromide. Sizes of restriction fragments were deduced by comparison with a 1 kb DNA ladder (Bethesda Research Laboratories, Paisley, Scotland).

\section{Results}

B CHAIN RELATED AMPLIFICATION

Using MboII (to detect insulin Chicago ${ }^{21}$ ) and HaeIII (as a general screen for polymorphism) four fragments were resolved, sized 20,39, 94, and 51 base pairs. Insulin Chicago would have resulted in three fragments of size 20,39, and 146 base pairs. In all 23 south Indian NIDDM subjects, of whom half possessed the class 3 allele, no polymorphism was detected, thus ruling out mutations at these restriction sites as a common cause of NIDDM in south Indians.

\section{A CHAIN RELATED AMPLIFICATION}

No polymorphisms were detected with PvuII in 23 south Indian NIDDM subjects, 13 of whom possessed the class 3 allele. Two patterns were detected with PstI; pattern $\alpha$ consisted of fragments sized 150, 27, and 41 base pairs whereas in pattern $\beta$ there was an extra $P$ stI site with fragments sized $65,85,27$, and 41 base pairs (figure). In subjects homozygous for the class 1 allele the allelic frequencies for pattern $\alpha$ and $\beta$ 


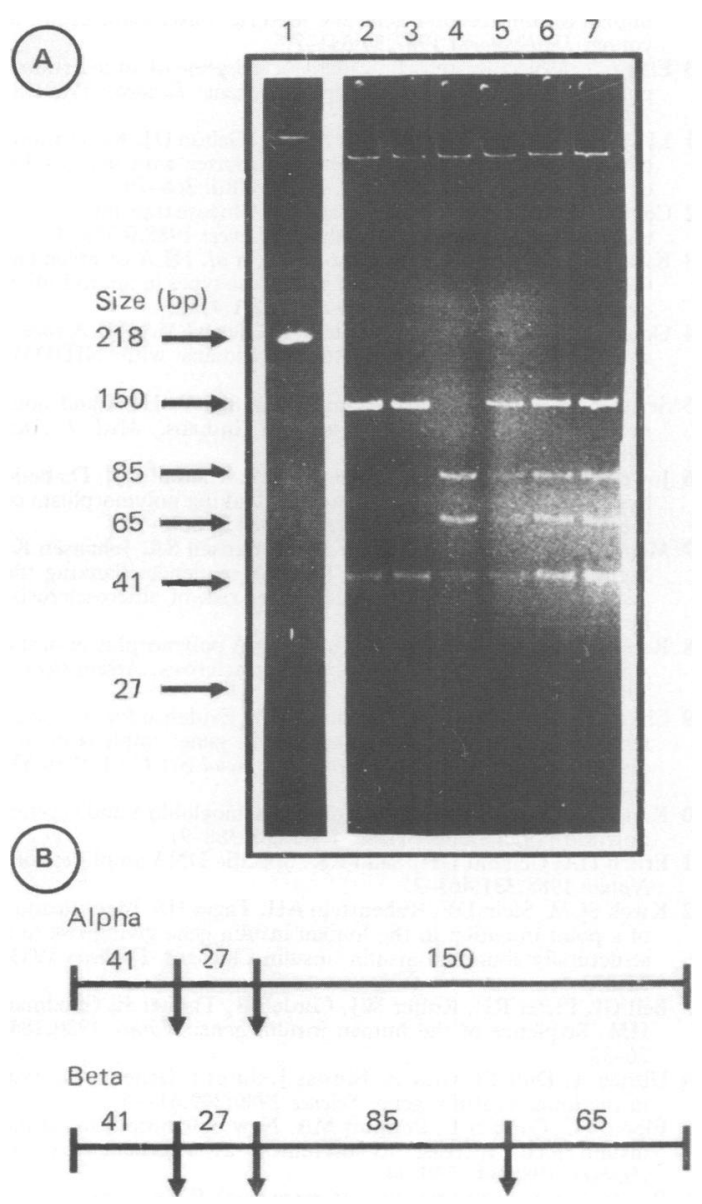

Amplified insulin gene products and PstI restriction map. (A) Photograph of polyacrylamide gel stained in ethidium bromide and transilluminated with ultraviolet light. Lane 1 is the insulin gene product and lanes 2 to 7 different subjects restricted with PstI. Subjects in lanes 2 and 3 are homozygous for $\alpha$, lane 4 homozygous for $\beta$, and lanes 5, 6, and 7 heterozygous $\alpha \beta$. Sizes to the left of the gel refer to sizes of the individual gene fragments in base pairs $(b p)$. Although the 27 base pair fragment cannot be seen on the photograph it was clearly visible on inspection of the original gel under an ultraviolet light source. (B) PstI restriction map of the $\alpha$ and $\beta$ alleles explaining the size variation detected in the experiments. Arrows refer to the presence of PstI restriction sites.

respectively were $0.94(143 / 152)$ and 0.06 , whereas in subjects homozygous for the class 3 allele the corresponding frequencies were $0 \cdot 18(4 / 22)$ and 0.82 , and in heterozygotes $(1,3) \quad 0.63(54 / 86)$ and $0.37(2 \times 3$ $\chi^{2}=78, p<0.0001$, Cramer's $\left.V=0.55\right)$. Thus, patterns $\alpha$ and $\beta$ were in linkage disequilibrium with the class 1 and class 3 alleles respectively in both south Indian and Punjabi Sikh populations, and were no more informative for diabetes than the insulin gene HVR flanking region polymorphism. It was therefore not
Frequencies of insulin gene $\alpha$ and $\beta$ alleles in study populations.

\begin{tabular}{llccc}
\hline & & \multicolumn{3}{c}{ Allelic frequency } \\
\cline { 4 - 5 } & & No & $\alpha$ & $\beta$ \\
\hline South Indian & Controls & 52 & 0.78 & 0.22 \\
& NIDDM & 46 & 0.72 & 0.28 \\
& FCPD & 52 & 0.75 & 0.25 \\
& MODY & 48 & 0.79 & 0.21 \\
Punjabi Sikhs & & & & \\
& Controls & 34 & 0.76 & 0.24 \\
& NIDDM & 28 & 0.85 & 0.15 \\
\hline
\end{tabular}

surprising that results in the south Indian population did not differ between the types of diabetes (NIDDM, MODY, and FCPD), nor between NIDDM and control subjects in the Punjabi Sikhs, although only small numbers were studied (table).

\section{Discussion}

Results from this study indicate (1) that at least one mutant insulin (insulin Chicago) is not a common cause of NIDDM in the south Indian population, and (2) in both the south Indian and Punjabi Sikh populations the class 3 allele in the $5^{\prime}$ flanking region of the insulin gene is in linkage disequilibrium with a point mutation in the $3^{\prime}$ untranslated region of the insulin gene (the two loci being physically separated by approximately $2 \mathrm{~kb}$ ), which therefore provides no more additional information than studying the insulin gene HVR itself.

The PstI intragenic insulin gene polymorphism was first described by Bell $e t a l^{23}$ and Ullrich et al. ${ }^{24}$ In the two alleles sequenced, a point mutation in the $3^{\prime}$ untranslated region at position 1628 involving a $\mathrm{C}$ to $\mathrm{A}$ transversion accounted for the presence (gHI $12 \cdot 5^{23} / \beta$ allele ${ }^{24}$ ) or absence (gHI $14 \cdot 1^{23} / \alpha$ allele ${ }^{24}$ ) of the PstI cutting site. Subsequently it was studied by Elbein $e a^{25}$ by Southern blot analysis in 50 alleles each from Caucasoids, Pima Indians, and blacks; they found it to be non-polymorphic and therefore concluded that the $\beta$ type allele represented an isolated mutation. ${ }^{25}$ From our studies this is clearly not the case, its frequency depending on the frequency of the class 3 allele in the study groups.

The next question which arises is could this point mutation which creates the extra PstI site in the $3^{\prime}$ untranslated (3UT) region be a mutation which provides a small part of the genetic susceptibility to non-insulin requiring diabetes in some south Indian subjects. The function of the 3UT is not known, although it does form part of the primary mRNA transcript; some authors have postulated that this region may be important for mRNA stability. ${ }^{26}$ Thus, a possible hypothesis is that this polymorphism may lead to less mRNA being translated and hence hypoinsulinaemia, thus causing NIDDM in south 
Indian subjects; this would be in keeping with recent thoughts on the aetiology of this disease. ${ }^{27}$ Alternatively, both the insulin gene HVR and the described PstI RFLP could be in linkage disequilibrium with sequences important to insulin regulation in the $5^{\prime}$ flanking region of the insulin gene.

Finally, it is worth highlighting the ease of the methodology used in this project in detecting possible aetiological mutations within coding regions of a gene without the need for Southern blot technology and the use of radioactive probes.

PKK was funded by the Medical Research Council. We thank $H$ Mather and $E$ Kohner for allowing us access to their patients.

1 Hitman GA, Niven MJ. Genes and diabetes mellitus. Br Med Bull 1989;45:191-205.

2 Owerbach D, Nerup J. Restriction fragment length polymorphism of the insulin gene in diabetes mellitus. Diabetes 1982;31:275-7.

3 Hitman GA, Jowett NI, Williams LG, Humphries S, Winter RM, Galton DJ. Polymorphisms in the 5 ' flanking region of the insulin gene and non-insulin-dependent diabetes. Clin Sci 1984;66:383-8.

4 Bell GI, Horita S, Kam JH. A highly polymorphic locus near the human insulin gene is associated with insulin-dependent diabetes mellitus. Diabetes 1984;33:176-83.

5 Nomura M, Iwama N, Mukai M, Saito Y, Kawamori R, Snichiri $M$, Kamada $T$. High frequency of class 3 allele in the human insulin gene in Japanese type 2 (non-insulin-dependent) diabetic patients with a family history of diabetes. Diabetologia 1986;29: 402-4.

6 Hitman GA, Karir PK, Mohan V, et al. A genetic analysis of type 2 (non-insulin-dependent) diabetes mellitus in Punjabi Sikhs and British Caucasoid patients. Diabetic Med 1987;4:526-30.

7 Kambo PK, Hitman GA, Mohan V, et al. The genetic predisposition to fibrocalculous pancreatic diabetes. Diabetologia 1989;32:45-51.

8 Takeda J, Seino Y, Yoshimass Y, et al. Restriction fragment length polymorphism (RFLP) of the human insulin receptor gene in Japanese: its possible usefulness as a genetic marker. Diabetologia 1986;29:667-9.

9 Elbein SC, Borecki I, Corsetti L, et al. Linkage analysis of the human insulin receptor gene and maturity onset diabetes of the young. Diabetologia 1987;30:641-7.

10 Elbein S. Molecular and clinical characterisation of an insertional polymorphism of the insulin receptor gene. Diabetes 1989;38: $737-43$.

11 Li SR, Baroni MG, Oelbaum RS, Stock J, Galton DJ. Associations of genetic variant of the glucose transporter with non-insulin dependent diabetes mellitus. Lancet 1988;ii:368-70.

12 Cox NJ, Xiang KS, Bell GI, Karam JH. Glucose transporter gene and non-insulin-dependent diabetes. Lancet 1988;ii:793-4.

13 Kirk RF, Ranford IR, Serjeantson SW, et al. HLA complement C2, C4, properdin factor B and glyoxylase types in South Indian diabetics. Diabetic Res Clin Pract 1985;1:41-5.

14 Omar MAK, Hammon MG, Motala AA, Seedaf MA. HLA class I and II antigens in South African Indians with NIDDM. Diabetes 1988;37:796-9.

15 Serjeantson SW, Ryan DP, Ram P, Zimmet P. HLA and noninsulin dependent diabetes in Puji Indians. Med $\mathcal{f}$ Aust 1981;1:462-3.

16 Jowett NI, Williams LG, Hitman GA, Galton DJ. Diabetic hypertriglyceridaemia and related 5 ' flanking polymorphism of the human insulin gene. Br Med f 1984;288:96-9.

17 Mandrup-Poulsen T, Owerbach D, Mortensen SA, Johansen K, Meinertz-Sorensen $\mathrm{H}$, Nerup J. DNA sequences flanking the insulin gene in chromosome 11 confer risk of atherosclerosis. Lancet 1984;i:253-5.

18 Rees A, Stocks J, Williams LG, et al. DNA polymorphisms of the Apo C111 and insulin genes and atherosclerosis. Atherosclerosis 1985;58:269-75.

19 Chakravarti H, Elbein SC, Permutt MA. Evidence for increased recombination near the human insulin gene: implication for disease association studies. Proc Natl Acad Sci USA 1986;83: 1045-9.

20 Kan YW, Dozy AM. Evolution of the haemoglobin S and C genes in world populations. Science 1980;209:388-91.

21 Erlich HA, Gelfand DH, Saiki RK. Specific DNA amplification. Nature 1988;331:461-2.

22 Kwok SCM, Stein DF, Rubenstein AH, Tager HS. Identification of a point mutation in the human insulin gene giving rise to a structurally abnormal insulin (insulin Chicago). Diabetes 1983; 32:872-5.

23 Bell GI, Pictet RL, Ruffer WJ, Cordell B, Tischer E, Goodman HM. Sequence of the human insulin gene. Nature 1980;284: 26-32.

24 Ullich A, Dull TJ, Gray A, Brosias J, Sures I. Genetic variation in the human insulin gene. Science 1980;209:612-5.

25 Elbein SC, Corsetti L, Permutt MA. New polymorphisms at the insulin locus increase its usefulness as a genetic marker. Diabetes 1985;34:1139-44.

26 Brawerman G. Determinants of messenger RNA stability. Cell 1987;48:5-6.

27 Temple RC, Carrington CA, Luzi SD, et al. Insulin deficiency in non-insulin-dependent diabetes. Lancet 1989;i:293-5. 